\title{
Tree Species Diversity and Forest Stand Structure of Pahang National Park, Malaysia
}

\author{
Mohd Nazip Suratman
}

Additional information is available at the end of the chapter

http://dx.doi.org/10.5772/50339

\section{Introduction}

Information on composition, diversity of tree species and species-rich communities is of primary importance in the planning and implementation of biodiversity conservation efforts. In addition, the diversity of trees is fundamental to the total tropical rainforest diversity as trees provide resources and habitat structure for almost other forest species (Cannon et al., 1998). According to Singh (2002), biodiversity is essential for human survival and economic well being and ecosystem function and stability. UNEP (2001) reported that habitat destruction, over exploitation, pollution and species introduction are identified as major causes of biodiversity loss. Hubbel et al. (1999) mentioned that disturbances created by these factors determine forest dynamics and tree diversity at the local and regional scales. These disturbances have been considered as an important factor structuring communities (Sumina, 1994).

In forest management operations, inventories on biodiversity are used to determine the nature and distribution of biodiversity region at the region being managed. Quantification of tree species diversity is an important aspect as it provides resources for many species (Cannon et al., 1998). Being a dominant life form, trees are easy to locate precisely and to count (Condit et al., 1996) and are also relatively better known, taxonomically (Gentry, 1992).

While Pahang National Park provides both fully-protected habitats and long-term maintenance of biological diversity, the structure and composition of its flora still remain rather insufficiently known. To protect forests from declining, it is essential to examine the current status of species diversity as it will provide guidance for the management of protected areas. Therefore, using Kuala Keniam forest as an example, a study was conducted to describe quantitatively stand structure of the forests of Kuala Keniam within Pahang National Park, and to determine the level of species composition, diversity and distribution in this area. Information from this quantitative inventory will provide a 
valuable reference for forest assessment and improve our knowledge in identification of ecologically useful species as well as species of special concern, thus identify conservation efforts for sustainability of forest biodiversity.

\section{Materials and methods}

\subsection{Description of study area}

The data for this study were collected from Kuala Keniam forest, Pahang National Park, Malaysia (latitude $4^{\circ} 31^{\prime} 07.17^{\prime \prime} \mathrm{N}$, longitude 102 $28^{\prime} 31.26^{\prime \prime} \mathrm{E}$ ) which ranges about $120-200 \mathrm{~m}$ above sea level. Kuala Keniam is located at the protected lowland dipterocarp forests within the national park in the state of Pahang. The area is administered by the Department of Wildlife and National Park (DWNP) Malaysia in collaboration with the Universiti Teknologi MARA (UiTM) which operates a research station in the area.

The weather in Pahang National Park is characterized by permanent high temperatures ranging from $20^{\circ} \mathrm{C}$ at night and $35^{\circ} \mathrm{C}$ in the day with a high relative humidity (above $80 \%$ ). Periods of sunshine in the morning are usually followed by heavy thunderstorms in the afternoon, sometimes accompanied by severe gusts of wind. The highest rainfall occurs in October to November with about $312 \mathrm{~mm}$ of rainfall. The lowest rainfall occurs in March with only about $50 \mathrm{~mm}$ of rain. Sedimentary rocks account for about $83 \%$ of National Park. The last formation of sedimentary rocks belongs to the Cretaceous-Jurassic era which exists in Kuala Keniam and its vicinity. The rocks are thick cross-bedded sandstone deposits with subordinate conglomerates and mudstones. The topography consists mainly of lowland, undulating and riverine areas and gently rolling hills with slopes of between $5^{\circ}$ to $45^{\circ}$.

The overall vegetation type in Pahang National Pahang is lowland dipterocarp forests in which is characterized by high proportion of species in the family of Dipterocarpaceae with Meranti (Shorea spp.) and Keruing (Dipterocarpus spp.) as the dominant species. Lowland dipterocarp forest is one of the most rich-species communities in the world, with more than 200 species ha $^{-1}$ (Okuda et al., 2003). Other vegetation communities in Pahang National Park range from the humid rainforests of the lowland, to the montane oak and ericaceous forests in the higher elevation. The highest peak is Mount Tahan 2,187 m, which also the highest point in Peninsular Malaysia. Tahan River and Tembeling River are the headstream tributaries of Pahang National Pahang with the presence riparian tree species, i.e., Gapis (Saraca multiflora), Keruing neram (Dipterocarpus oblongifolius), Merbau (Intsia palembanica), Kasai daun bersar (Pometia pinnata) and Melembu (Pterocambium javanicum), along river banks. The rainforest consists of tall evergreen trees which attain heights between $30-50 \mathrm{~m}$ (i.e., Tualang - Koompassia excelsa).

\subsection{Sampling design and data collection}

A topographic map was used to locate the existing forest trails and baselines in the forest area. A total of five transect lines of $100 \mathrm{~m}$ in length and $20 \mathrm{~m}$ in width (abbreviated as T1, T2, T3, T4 and $\mathrm{T} 5$ thereafter) were established in east-west direction using a compass (Table 1, Figure 1). 
Each transect line was gridded into five plots, each $20 \mathrm{~m} \times 20 \mathrm{~m}$ in size, as workable units. These transect lines were perpendicular to the existing baseline in the forest area and constructed $5 \mathrm{~m}$ after the line. The topographic position, including the gradient was measured at each plot. The slope was measured using a clinometer. A tape measure was used to mark the transect lines at the intervals of $20 \mathrm{~m}$. All trees with a diameter at breast height (DBH, $1.3 \mathrm{~m}$ above the ground) above $10 \mathrm{~cm}$ were measured, tagged and identified by species. The $\mathrm{DBH}$ was measured using a $\mathrm{DBH}$ tape. If field identification was not possible, the botanical specimens were taken to the herbarium section of the Forest Research Institute Malaysia (FRIM) for identification.

\begin{tabular}{ccccl}
\hline Transect & No. of plots & Area $\left.\mathbf{( m}^{\mathbf{2}}\right)$ & Slope $(\mathbf{o})$ & \multicolumn{1}{c}{ Topography } \\
\hline T1 & 5 & $20 \times 20$ & $5-35$ & Steep lower slope with riverine areas \\
T2 & 5 & $20 \times 20$ & $3-20$ & Gentle to mid-slope \\
T3 & 5 & $20 \times 20$ & $0-10$ & Mainly flat and gentle slope \\
T4 & 5 & $20 \times 20$ & $3-30$ & Mid-slope with riverine areas \\
T5 & 5 & $20 \times 20$ & $0-10$ & Mainly flat and gentle slope \\
\hline
\end{tabular}

Table 1. General features of sample plot within the five transect lines of the study area.

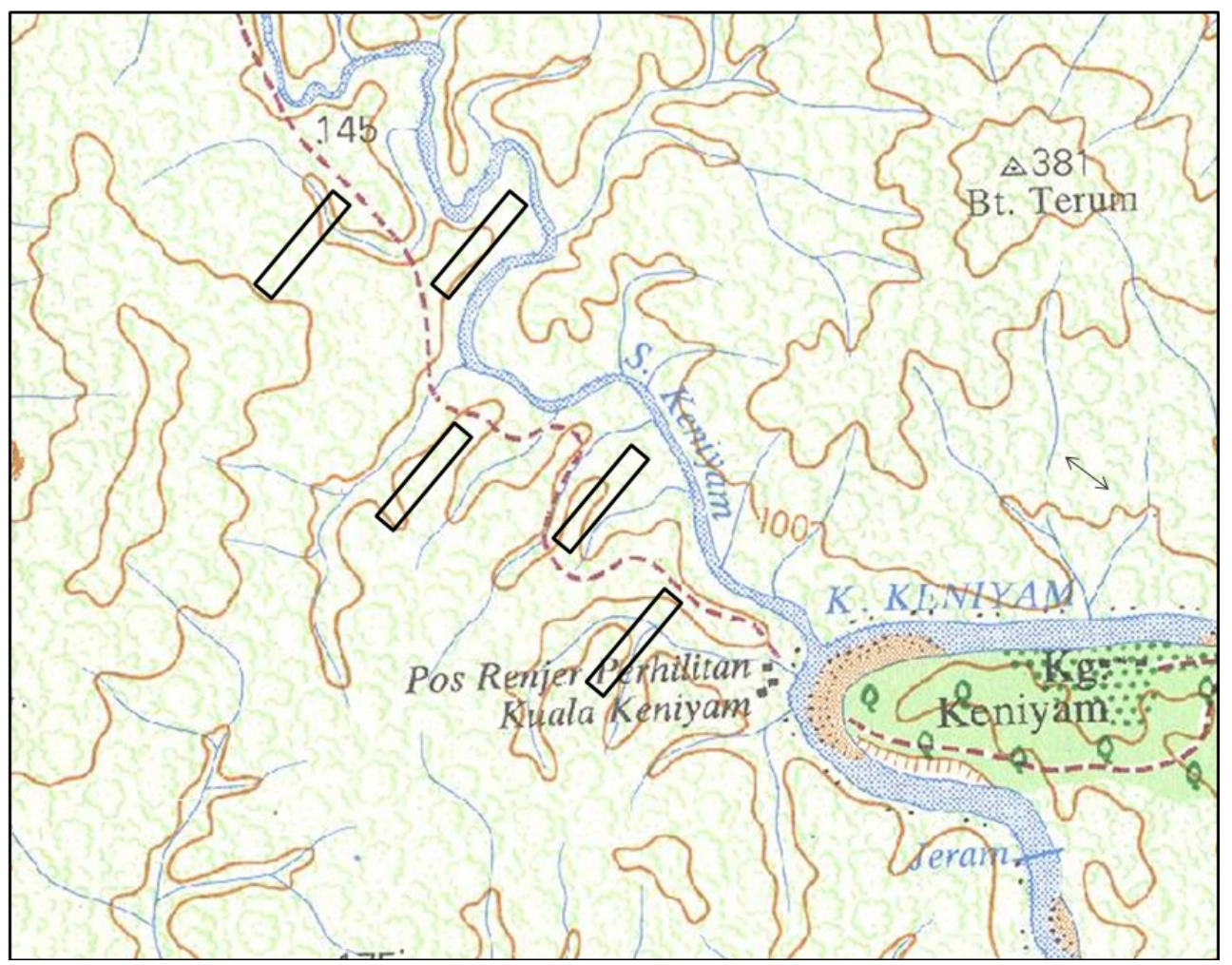

Figure 1. A map of the study area shows the location of five transect lines. 


\subsection{Data analysis}

The means of basal area, genera, species and stem per hectare were calculated for each transect line. One-way analysis of variance (ANOVA) was used to test the differences between the means of these parameters using SAS system (SAS Institute, 2000). The relative dominance of species in each transect line was identified on the basis of relative basal area. The relative basal area of a species on transect lines was calculated as the basal area of a species divided by total basal area of the site and multiplied with 100. The dominant and codominant species of each site were identified based on this value. The species with the highest relative basal area was defined as dominant and that with the second highest relative basal area was defined as co-dominant.

In this study, the stand structure was described based on the distribution of species in the study sites and distribution of trees by diameter classes. Therefore, the tree data were grouped into $5 \mathrm{~cm}$ diameter classes e.g., the class boundaries were $10-14.9,15-19.5 \mathrm{~cm}$, etc. These gave a frequency of trees in each diameter class and were then used to draw bar char graphs.

\subsection{Basal area}

Basal area is a measure of tree density that defines the area of a given section of land that is occupied by the cross-section of tree. Basal area $(B A)$ is calculated using the following equation that converts the $\mathrm{DBH}$ in $\mathrm{cm}$ to the basal area in $\mathrm{m}^{2}$.

$$
\begin{gathered}
B A=\pi r^{2} \\
=3.142 \times\left(\frac{\mathrm{dbh}}{200}\right)^{2}
\end{gathered}
$$

Where

$B A=$ tree basal area $(\mathrm{m} 2)$

$\mathrm{r}=$ radius $(\mathrm{cm})$

\subsection{Species diversity, richness and evenness indices}

A variety of different diversity indices can be used as measures of some attributes of community structure because they are often seen as ecological indicators (Magurran, 1988). Diversity indices provide important information about rarity and commonness of species in a community. The indices can be used to compare diversity between habitat types (Kent and Coker, 1992). The comparison can be between different habitats or a comparison of one habitat over time. Different diversity, species richness, species evenness indices were calculated for each transect as well as pooled data for all transects.

a. Shannon-Weiner diversity index $\left(H^{\prime}\right)$ (Shannon and Weiner, 1949) is calculated using the following equation: 


$$
H^{\prime}=\sum_{i=1}^{s} p_{i} \ln p_{i}
$$

Where

$H^{\prime}=$ the Shannon-Wiener index

$p_{i}=$ the proportion of individuals belonging to species $i$

$\ln =$ the natural $\log$ (i.e., 2.718 )

b. The species richness (number of species per unit area) was calculated using Margalef index of species richness (Margalef, 1958) as follows:

$$
\mathrm{SR}=\frac{S-1}{\ln (N)}
$$

Where

$S R=$ the Margalef index of species richness

$S=$ the number of species

$N=$ the total number of individuals

c. The Whittaker's index of species evenness (Whittaker, 1972) was calculated using the following equation:

$$
E_{w}=\frac{S}{\ln N_{i}-\ln N_{s}}
$$

Where

$E_{w}=$ the Whittaker's index of evenness

$N_{i}=$ the abundance of most important species

$N_{s}=$ the abundance of the least important species

d. $\alpha$-diversity was measured based on unified indices (exponential Shannon-Weiner index and Simpson's diversity) as follows:

$$
N_{1}=\exp ^{H^{\prime}}
$$

Where

$N_{1}=$ the number of equally common species

$H^{\prime}=$ the Shannon-Weiner index

e. Simpson's diversity $(D)$ (Simpson, 1949) was calculated using the following equation:

$$
D=1-\lambda
$$

Where

$\mathrm{D}=$ the Simpson diversity 
$\lambda=$ the Simpson's concentration of dominance calculated as $\sum p_{i}^{2}$.

f. The Whittaker's index of $\beta$-diversity (Whittaker, 1972) was calculated as:

$$
\beta w=\frac{S_{c}}{\bar{S}}
$$

Where

$\beta_{w}=$ the Whittaker's index of $\beta$-diversity

$S_{\mathrm{c}}=$ the total number of species

$\bar{S}=$ the average number of species per sample

g. Bray-Curtis index $\left(C_{N}\right)$ (Bray and Curtis, 1947), a similarity coefficient, is used to measure similarity between transect lines.

$$
C_{N}=\frac{2 j N}{(a N+b N)}
$$

Where

$C_{N}=$ the Bray-Curtis index

$a N=$ individual numbers of plot $\mathrm{A}$

$b N=$ individual numbers of plot $\mathrm{B}$

$j N=$ the sum of less individual numbers of each species common in plots $\mathrm{A}$ and $\mathrm{B}$

\section{Results and discussion}

\subsection{Stand structure analysis of different sites}

Information on the basal area, stem, species and genera densities are efficient expression for revealing forest stand structure and spatial distribution of trees present in the landscape. These four parameters are presented in Table 2. In this study, the means of basal area ha-1, stem ha-1, species ha-1 and genera ha-1 were measured in every plot $(20 \mathrm{~m} \times 20 \mathrm{~m})$ and were averaged to provide an estimate for each transect line. From the analysis of variance, it was found that the difference in the means of these parameters among transects were not statistically significant at $\mathrm{P} \leq 0.05$.

The mean of basal area obtained in the present study ranged from $17.2 \mathrm{~m}^{2} \mathrm{ha}^{-1}$ (T4) to 34.3 $\mathrm{m}^{2}$ ha $^{-1}$ (T3) (Table 2), which is lower compared to those recorded in other tropical rainforests. Examining the structure and composition of lowland tropical rainforests in north Borneo, Burgess (1961) recorded a basal area of $73.6 \mathrm{~m}^{2} \mathrm{ha}^{-1}(\geq 10 \mathrm{~cm} \mathrm{DBH})$ over a small area (0.08 ha) at Gum Gum Sabah. In another study in an evergreen forest of Andaman Islands, basal area of $44.6 \mathrm{~m}^{2} \mathrm{ha}^{-1}$ has been recorded in 4.5 ha sampled area (Padalia et al., 2004). A much lower basal area of $29 \mathrm{~m}^{2}$ ha-1 and $5.6 \mathrm{~m}^{2}$ ha-1 have been recorded in logged over forest of Sungkai, Perak (Suratman et al., 2007) and secondary forests of Sungai Sator, Kelantan (Suratman et al., 2009), respectively. Both are secondary forests and were put under a selection system of timber extraction in the past, and are considered to be of poor species. 


\begin{tabular}{lccccc}
\hline Variables & T1 & T2 & T3 & T4 & T5 \\
\hline Mean basal area $\left(\mathrm{m}^{2}\right.$ ha $\left.^{-1}\right)$ & 25.2 & 24.8 & 34.3 & 17.2 & 33.3 \\
& $(25.2)$ & $(13.3)$ & $(15.1)$ & $(16.0)$ & $(12.2)$ \\
Mean no. of stems ha- & 510 & 430 & 505 & 315 & 480 \\
& $(123.3)$ & $(105.2)$ & $(51.2)$ & $(219.8)$ & $(186.6)$ \\
Mean no. of species ha- & 370 & 370 & 450 & 280 & 405 \\
& $(105.2)$ & $(105.2)$ & $(30.6)$ & $(190.7)$ & $(125.5)$ \\
Mean no. of genera ha-1 & 340 & 340 & 435 & 250 & 365 \\
Total no. of species per individual & $(72.0)$ & $(72.0)$ & $(51.8)$ & $(165.8)$ & $(109.8)$ \\
\hline
\end{tabular}

Note: The values in parentheses are standard deviation. All means for the first four parameters above are not significantly different at $\mathbf{P} \leq 0.05$.

Table 2. The stand structure of Kuala Keniam forest.

The density and size distribution of trees contribute to the structural pattern characteristic of rainforests. In primary tropical rainforests, the density of trees varies within the limits and depends on many factors. The means number of species and stems per hectare on different transects varied from 280 (T4) - 450 (T3) and 315 (T4) - 510 (T1), respectively (Table 2), indicating a mixed nature of distribution of species and individuals in the forest at each transect, a characteristic of the tropical rainforests. The factors controlling tree density include the effects of natural and anthropogenic disturbance and soil condition (Richards, 1952). From the field observation, the reserve area of the primary forest in the study sites is generally homogenous, with no evidence of major disturbance, and appeared to be a representative example of the lowland forest of Kuala Keniam.

Information on the density-dependent status of species in the study site is important for conservation and management. Studies have classified the density of trees ha ${ }^{-1}$ in tropical forests ranges from low values of 245 stems ha-1 (Ashton, 1964; Campbell et al., 1992; Richards, 1996) intermediate values of 420 - 617 stems ha-1 (Campbell et al., 1992) in Brazilian Amazon and high values of 639 - 713 stems ha-1 in Central Amazon upland forests (Ferreira et al., 1998). In the present study, the density of stems per hectare ranged from 315 - 510 stems ha $^{-1}$, reflecting spatial variability in the sampled sites. The range fell within intermediate category in the above studies. In the Neotropics, the maximum richness is found up to 300 stems ha $^{-1}$ (Gentry, 1988). A much lower result was reported for forests in Africa where the species richness is about 60 stems ha-1 $^{-1}$ Bernhard-reversat et al., 1978).

Tree species composition in tropical areas varies greatly from one place to another mainly due to variation in biogeography, habitat and disturbance (Whitmore, 1998). In the tropical rainforests, the tree species per hectare ranges from about 20 to a maximum of 223 (Whitmore, 1984). Philips and Gentry (1994) reported a range of $56-282$ species ha- $^{-1}(>10 \mathrm{~cm}$ $\mathrm{DBH}$ ) in mature tropical forests. In the present study, a range of 280 to 450 species ha-1 has been recorded in the lowland rainforest of Kuala Keniam (Table 2). In the very rich rainforests, the number of species in rainforests could be as high as 400 species ha-1 $^{-1}$ (Nwoboshi, 1982). When compared to some rainforests around the world, the lowland rainforest of Kuala Keniam could be considered to be species rich. Tropical rainforests in 


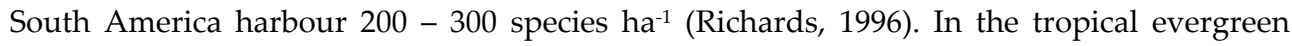
forest of Andaman Islands, India, Padalia et al. (2004) found that 58 tree species ha-1 were recorded belong to 176 genera and 81 families.

The mean numbers of genera per hectare varied from 340 to 435 genera ha ${ }^{-1}$. These values are much higher than that obtained by Sagar et al. (2003) at a dry tropical forest region of India $\left(4-22\right.$ genera ha- $\left.^{-1}\right)$. T4 had the highest total number of species per individual when compared to the other four sites of study. The difference could be due to genetic and site difference. A study on vegetation types in Yunnan, Chiangcheng et al. (2007) found that slope direction had influence on the tree diversity at different altitudes. The tree diversity on the sunny slope was lower than that on shady slope. The difference in terrain, gradient and slope direction causes the difference soil, water and microclimate which may cause of differences in species adaptability.

\subsection{Dominant tree species}

On the basis of relative basal area, the five sites differed in the combination of dominant and co-dominant species (Appendix). Elateriospermum tapos was dominant in T1 and co-dominant in T4. Koompassia malaccensis dominated at the T2 and co-dominated at the T3. Xanthophyllum lelacarum was dominant in T3 while Shorea leprosula was dominant in T4. Dyera costulata and Dipterocarpus costulatus were dominated and co-dominated at T5, respectively. Thus, the species exhibit local dominance. These data revealed that T1 represented Elateriospermum-Intsia community; T2, Koompassia-Pentaspadon community; T3, Xanthophyllum-Koompassia community; T4, Shorea-Koompassia community; and T5, Dyera-Dipterocarpus community. Two tree species, i.e., Alphonsea elliptica and Syzygium sp., are common on all transects.

\subsection{Species diversity}

The five transect lines yielded a total of 448 stems and 198 species of trees $\geq 10 \mathrm{~cm} \mathrm{DBH}$. These species represent 116 genera and 44 families (Appendix). The number of species and individual varied from 50 to 64 species and 63 to 102 individuals per transect of $100 \mathrm{~m} \times 20$ $\mathrm{m}$ size, respectively. Table 3 shows the summary statistics for various indices of diversity, richness and evenness. It is generally recognized that the area and environmental heterogeneity have strong effects on species diversity (Rosenzweig, 1995; Whitmore, 1998; Waide et al., 1999). The Shannon-Weiner index $\left(H^{\prime}\right)$ was used to compare species diversity between transects. The $H^{\prime}$ for T1-T5 were 3.42, 3.91, 3.97, 3.84 and 3.91, respectively, indicating that among transects, T3 was the most complex in species diversity whereas T1 is the simplest community in terms of species composition. The Shannon-Weiner diversity index (range between 3.42 - 3.91) obtained for trees more than $10 \mathrm{~cm} \mathrm{DBH}$ in this study was lower than those recorded in the tropical rainforests of Barroo Colorado Island, Panama [4.8](Knight, 1975) and Silent Valley, India [4.89](Singh et al., 1981). In a more recent study in Shenzen, China, Wang et al. (2006) recorded a lower range of Shannon-Weiner index (i.e., $1.92-3.10$ ) for trees $\geq 2 \mathrm{~cm} \mathrm{DBH}$ in a subtropical forest. However, a comparison of diversity indices obtained in the present study with the ones above is difficult due to vast differences in the area sampled, plot size, and the standard diameter class taken. 


\begin{tabular}{lccccc}
\hline Variables & T1 & T2 & T3 & T4 & T5 \\
\hline Shannon-Weiner index $\left(H^{\prime}\right)$ & 3.42 & 3.91 & 3.97 & 3.84 & 3.91 \\
Margalef index of species richness $(S R)$ & 10.81 & 13.02 & 13.65 & 11.83 & 13.15 \\
Whittaker index of evenness $\left(E_{w}\right)$ & 16.04 & 36.66 & 35.72 & 44.60 & 31.35 \\
The number of equally common species $\left(N_{1}\right)$ & 30.72 & 49.72 & 53.11 & 46.55 & 49.75 \\
Simpson's diversity $(D)$ & 0.93 & 0.98 & 0.98 & 0.98 & 0.97 \\
Whittaker index of $\beta$-diversity $\left(\beta_{w}\right)$ & 3.51 & 3.88 & 3.56 & 4.46 & 3.77 \\
\hline
\end{tabular}

Table 3. Pattern of tree species diversity in Kuala Keniam forest.

Similar patterns were found for species richness, which was computed using Margalef index of species richness $(S R)$ and the number of equally common species $\left(N_{1}\right)$. The $S R$ ranged from 10.81 to 3.97 and the $N_{1}$ ranged from 30.72 to 53.11 . Whittaker index of evenness $\left(E_{w}\right)$ ranged from 16.04 to 44.60 , the highest value was recorded at T4 and the lowest at T1. In the present study, Simpson's diversity $(D)$ was not a very sensitive indicator of diversity as four of five sites (T2 - T5) had somewhat similar values. Whittaker index of $\beta$-diversity $(\beta w)$ was used to compare habitat heterogeneity within a transect. The $\beta$ w value was the highest for T4 (4.46) and the lowest for T1 (3.51). Further analysis indicated that the number of species per individual had a direct positive influence on $\beta$-diversity (Figure 2). According to Condit et al. (1998), species richness is positively associated with species abundance. This relationship suggests that large population is less prone to extinction than small ones (Preston, 1962). Based on the relationship between abundance and diversity, habitats supporting larger numbers of individuals can support more populations and more species than habitat supporting small number of individuals.

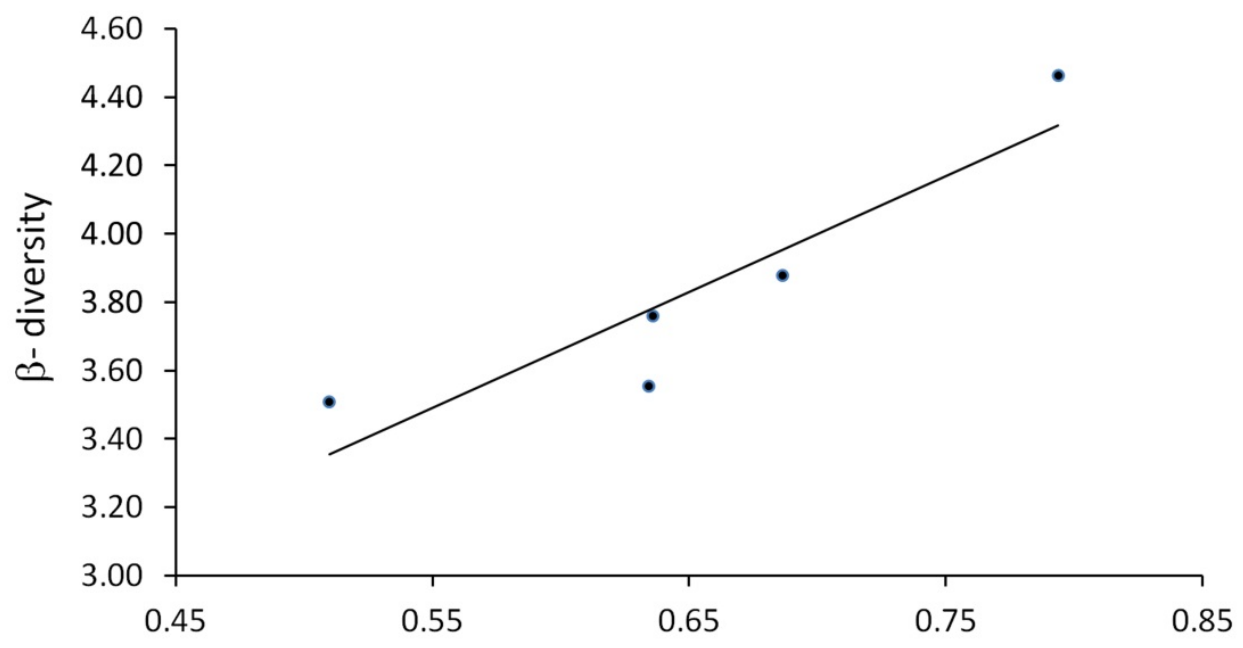

Species /individual

Figure 2. Relationship between $\beta$-diversity $\left(\beta_{\mathrm{w}}\right)$ and species/individual $\left(\mathrm{S}_{\mathrm{n}}\right)$ according to $\beta_{\mathrm{w}}=1.624$ $+3.393 S_{n}, r^{2}=83, p=0.03$. 


\subsection{Similarity between transects}

The similarity based on Bray-Curtis index $\left(C_{N}\right)$ was calculated between the pair of transects, and abundance similarity matrix was constructed (Table 4). The Bray-Curtis similarity index was used because it is often a satisfactory coefficient for biological data on community structure (Clarke and Warwick, 1994). Comparison of $C_{N}$ values among the five transects data indicates that the species composition of T1 was fairly different from those of the other four sites. T3 had a high species similarity to T4 and T5, and T4 had a high species similarity to T5. T2 was similar to some degree to T4 and T5.

\begin{tabular}{ccccc}
\hline Transect & T1 & T2 & T3 & T4 \\
\hline T2 & 0.15 & & & \\
T3 & 0.14 & 0.19 & & \\
T4 & 0.13 & 0.13 & 0.27 & 0.29 \\
T5 & 0.14 & 0.11 & 0.37 & \\
\hline
\end{tabular}

Table 4. Similarity coefficient among the five transects of Kuala Keniam forest.

\subsection{Family-wise distribution}

A total of 44 tree families were encountered in the forest of Kuala Keniam (Figure 3). The maximum number of tree species belongs to the family of Euphorbiaceae which accounts for $23.9 \%$ of the total individuals encountered in the study site. Elateriospermum tapos is the most widely occurring species from this family. Other trees from this family such as Macaranga lowii, Mallotus leucodermis and Pimelodendron griffithianum are among the important part of floristic composition in the study area. The other dominant families are Myristicaceae, Burseraceae, and Leguminosae which account for $8.3 \%, 5.4 \%$ and $4.5 \%$ of the total individual encountered in the study site, respectively. The fifth most dominant family is Myrtaceae with $4.2 \%$. Earlier study also indicated that Euphorbiaceae was the dominant family in Sungkai forest with $27 \%$ of tree species belong to this family (Suratman et al., 2007). Two other studies conducted in India for tree species also support the fact that Euphorbiaceae is the dominant family in Bay Islands (Dagar and Singh, 1999) and Andaman Islands (Padalia et al., 2004). The dominant plant family in Neotropical lowland forests and Africa is Leguminosae (Gentry, 1988) and in Southeast Asia the dominants are Dipterocarpaceae (Richards, 1952; Whitmore, 1998).

\subsection{Diameter class distribution}

The stand structure of lowland rainforests of Kuala Keniam forest was studied based on the distribution of tree diameter class. The diameter distribution of trees is very variable and some forests have large numbers of trees of $40-60 \mathrm{~cm}$ DBH (Richards, 1952). In this study, the distribution of trees clearly displays the characteristic of De iocourt's factor procedure (inverse J distribution) where stems frequencies decrease with the increase in DBH (Figure 4). This generally indicates that stands are developing and regeneration in the forest is 


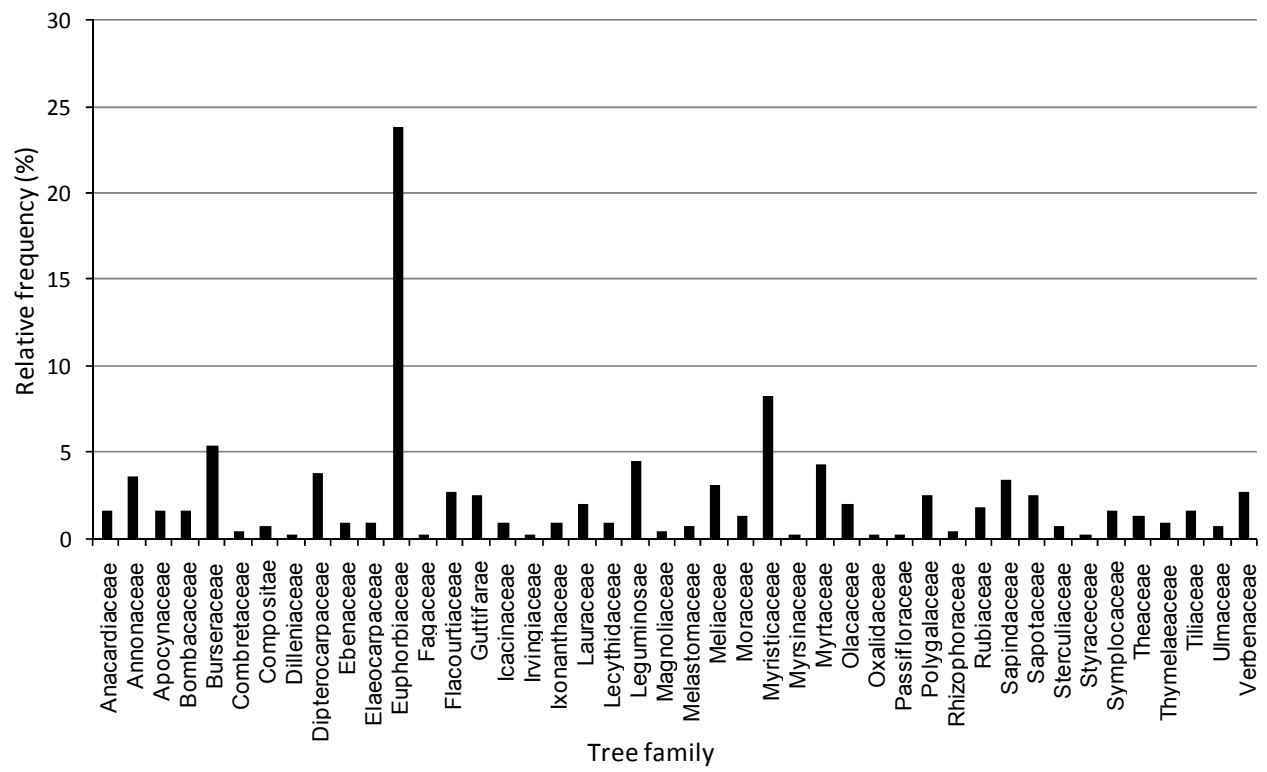

Figure 3. Family-wise distribution of tree species of Kuala Keniam forest.

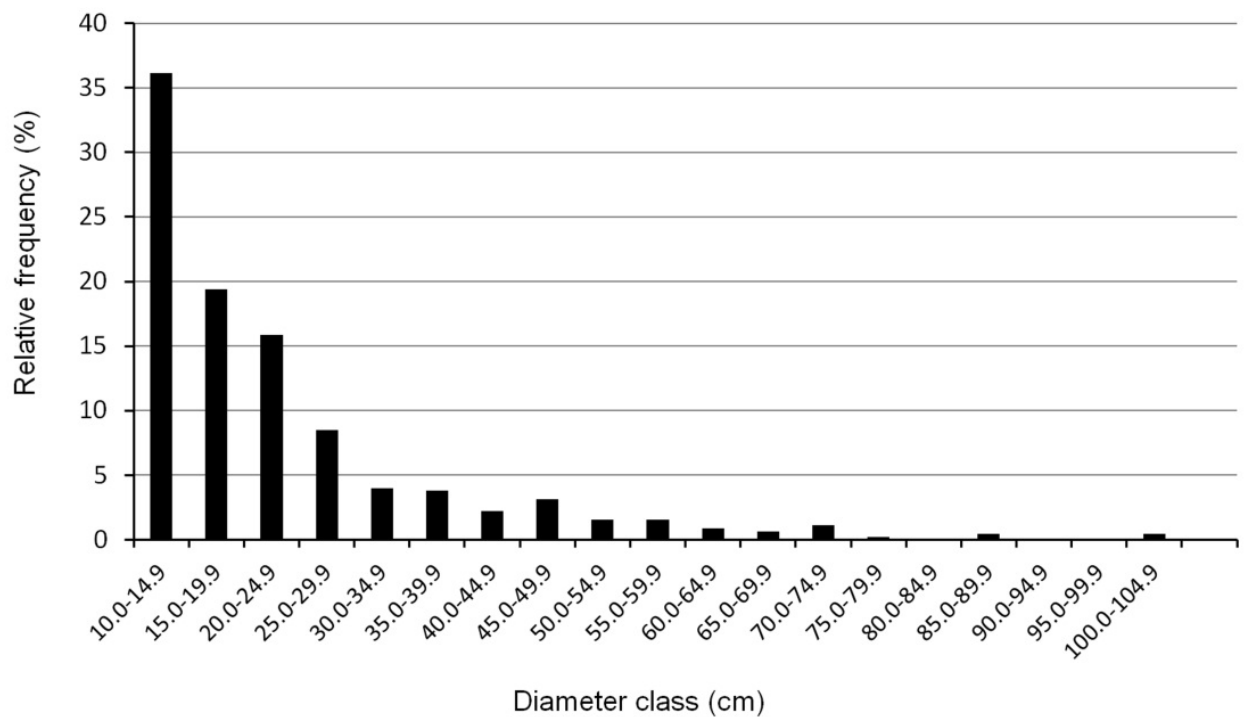

Figure 4. Diameter distribution of trees at Kuala Keniam forest. 
present. Natural regeneration is dependent on the availability of mother trees, fruiting pattern and favourable conditions. As shown in the figure, the presence of growth of the forest is indicated by the movement of trees in various diameter classes. Higher number of stems for smaller diameter classes, with $36 \%$ of trees fell within the $10-14.9 \mathrm{~cm}, 19 \%$ fell within $15-19.9 \mathrm{~cm}, 16 \%$ fell within $20-24.9 \mathrm{~cm}, 9 \%$ fell within $25-29.9 \mathrm{~cm}$ and $4 \%$ fell within $30-34.9 \mathrm{~cm}$. The histogram shows a less or an absent number of stems in diameter classes from $79.9 \mathrm{~cm}$ onwards. Under natural conditions, an old, big emergent tree may fall down and create gap. Forest regeneration via natural succession will take place if the area is not too far away from mature primary forest trees serving as source for the recalcitrant seeds.

\section{Conclusion}

The forests of Kuala Keniam are protected primary forests which comprises of natural vegetation and are dictated by a combination of biotic and abiotic factors like topography, altitude, geology, climatic etc. as well as historical conditions of geology and climate. The density and size distribution of trees contribute to the structural pattern characteristics of the forest. The study indicated that the forests of Kuala Keniam are characterized by a uniform distribution of individuals with mixed species composition, and the sites are represented by different combinations of the dominants and co-dominant species. The distribution of trees displays the characteristic of De iocourt's factor procedure (inverse J distribution) where stems frequencies decrease with the increase in $\mathrm{DBH}$, indicating stable populations in which regeneration of forest in this area is present.

\section{Appendix}

List of species, family and the relative basal area of Kuala Keniam forest

\begin{tabular}{llccccc}
\hline Species & Family & T1 & T2 & T3 & T4 & T5 \\
\hline Aglaia sp. & Meliaceae & - & 2.65 & 0.23 & 0.37 & 0.17 \\
Agrostistachys longifiolia & Euphorbiaceae & - & 0.26 & - & - & - \\
Aidia densiflora & Rubiaceae & - & - & 0.21 & - & 0.24 \\
Alphonsea elliptica & Annonaceae & 2.37 & 0.55 & 1.48 & 5.91 & 1.41 \\
Alphonsea jengkasii & Annonaceae & - & - & - & - & 0.16 \\
Alseodaphne intermedia & Lauraceae & - & - & 0.84 & - & - \\
Anisoptera laevis & Dipterocarpaceae & - & - & 4.35 & - & - \\
Antidesma coriaceum & Euphorbiaceae & - & - & 0.47 & - & - \\
Antisdesma sp. & Euphorbiaceae & - & 0.28 & - & - & - \\
Aporosa arborea & Euphorbiaceae & 0.51 & - & - & - & - \\
Aporosa aurea & Euphorbiaceae & - & 0.28 & - & - & -
\end{tabular}




\begin{tabular}{|c|c|c|c|c|c|c|}
\hline Species & Family & T1 & T2 & T3 & $\mathrm{T} 4$ & T5 \\
\hline Aporosa falcifera & Euphorbiaceae & - & - & - & 1.63 & 0.21 \\
\hline Aporosa globifera & Euphorbiaceae & - & 0.25 & - & - & - \\
\hline Aporosa microstachya & Euphorbiaceae & - & - & - & - & 0.22 \\
\hline Aporosa nigricans & Euphorbiaceae & - & 0.29 & - & - & - \\
\hline Aporosa prainiana & Euphorbiaceae & - & - & - & 0.24 & 0.12 \\
\hline Aporosa symplocoides & Euphorbiaceae & - & - & - & - & 0.17 \\
\hline Archidendron ellipticum & Leguminosae & - & - & 0.32 & - & - \\
\hline Ardisia sp. & Myrsinaceae & - & 0.21 & - & - & - \\
\hline Aromadendron elegans & Myristicaceae & - & 1.42 & - & - & - \\
\hline Artocarpus griffithii & Moraceae & - & - & 0.48 & - & - \\
\hline Artocarpus lowii & Moraceae & - & - & - & - & 0.73 \\
\hline Austrobuxus nitidus & Euphorbiaceae & - & - & - & - & 5.10 \\
\hline Baccaurea brevipes & Euphorbiaceae & - & - & - & 0.24 & - \\
\hline Baccaurea kunstleri & Euphorbiaceae & - & - & - & 0.42 & - \\
\hline Baccaurea minor & Euphorbiaceae & - & 0.72 & 2.77 & - & - \\
\hline Baccaurea reticulata & Euphorbiaceae & - & - & - & 0.38 & 3.46 \\
\hline Barringtonia macrostachya & Lecythidaceae & - & - & 0.28 & 0.37 & 0.20 \\
\hline Beilschmiedia lucidula & Lauraceae & - & - & 0.99 & - & - \\
\hline Blumeodendron kurzii & Euphorbiaceae & - & - & 0.82 & - & - \\
\hline Buchanania sessifolia & Anacardiaceae & - & - & 0.79 & - & 0.28 \\
\hline Callicarpa maingayi & Verbenaceae & - & - & - & - & 0.39 \\
\hline Callophyllum sp. & Guttiferae & - & 0.40 & - & - & - \\
\hline Canarium littorale & Burseraceae & 1.20 & - & 2.00 & - & - \\
\hline Carallia brachiata & Rhizophoraceae & - & - & - & - & 0.75 \\
\hline Casearia clarkei & Flacourtiaceae & - & - & 0.61 & 0.94 & 0.13 \\
\hline Casearia sp.1 & Flacourtiaceae & - & 0.91 & - & - & - \\
\hline Cheilosa malayana & Euphorbiaceae & - & 0.21 & - & 0.35 & - \\
\hline Chisocheton sp. & Meliaceae & 0.25 & - & - & - & - \\
\hline Cinnamomum iners & Lauraceae & - & 1.55 & - & - & - \\
\hline Croton levifolium & Euphorbiaceae & - & - & - & - & 0.29 \\
\hline Cryptocarya densiflora & Lauraceae & - & - & 0.61 & - & - \\
\hline Cryptocarya infectoria & Lauraceae & - & - & - & - & 0.45 \\
\hline Cryptocarya kurzii & Lauraceae & - & 0.63 & 0.50 & - & - \\
\hline Dacryodes costata & Burseraceae & - & - & 0.24 & - & - \\
\hline Dacryodes rostrata & Burseraceae & 0.59 & - & 0.13 & 0.31 & 4.79 \\
\hline
\end{tabular}




\begin{tabular}{|c|c|c|c|c|c|c|}
\hline Species & Family & T1 & T2 & T3 & $\mathrm{T} 4$ & T5 \\
\hline Dacryodes rugosa & Burseraceae & 0.48 & - & 0.19 & 1.08 & 0.18 \\
\hline Dialium indum L. var. indum & Leguminosae & 0.74 & - & - & - & - \\
\hline Dialium platysepalum & Leguminosae & - & 0.82 & - & - & - \\
\hline Dillenia reticulata & Dilleniaceae & - & 6.69 & - & - & - \\
\hline Diospyros buxifolia & Ebenaceae & - & - & 0.18 & - & - \\
\hline Diospyros maingayi & Ebenaceae & - & - & - & - & 1.87 \\
\hline Diospyros sumatrana & Ebenaceae & - & - & - & - & 0.28 \\
\hline Diplospora malaccensis & Rubiaceae & - & 0.28 & - & - & 0.57 \\
\hline Dipterocarpus costulatus & Dipterocarpaceae & - & - & - & - & 12.63 \\
\hline Durio griffithii & Bombacaceae & 0.28 & - & 1.67 & 0.33 & 0.68 \\
\hline Durio lowianus & Bombacaceae & - & - & - & 5.03 & - \\
\hline Dyera costulata & Apocynaceae & - & - & 0.84 & 2.97 & 13.38 \\
\hline Dysoxylum flavescens & Meliaceae & - & - & 1.71 & - & - \\
\hline Dysoxylum sp. & Meliaceae & 1.19 & - & - & - & - \\
\hline Dysoxylum sp1. & Meliaceae & - & - & 2.91 & - & - \\
\hline Elaeocarpus nitidus & Elaeocarpaceae & - & - & 0.30 & 1.13 & - \\
\hline Elaeocarpus palembanicus & Elaeocarpaceae & - & - & - & - & 0.13 \\
\hline Elaeocarpus petiolatus & Elaeocarpaceae & - & - & - & 0.68 & - \\
\hline Elateriospermum tapos & Euphorbiaceae & 16.11 & - & 4.48 & 7.73 & 3.40 \\
\hline Erythrospermum candidum & Flacourtiaceae & - & 0.34 & - & - & - \\
\hline Flacourtia rukam & Flacourtiaceae & 0.33 & - & - & - & - \\
\hline Garcinia bancana & Guttiferae & - & - & - & - & 3.96 \\
\hline Garcinia griffithii & Guttiferae & - & - & - & 0.75 & 3.18 \\
\hline Garcinia nervosa & Guttiferae & - & - & - & - & 1.79 \\
\hline Garcinia parvifolia & Guttiferae & - & - & 1.03 & - & - \\
\hline Garcinia pyrifera & Guttiferae & - & - & 0.40 & - & - \\
\hline Gironniera nervosa & Ulmaceae & 0.26 & - & - & - & - \\
\hline Gironniera subaequalis & Ulmaceae & - & - & 0.77 & - & - \\
\hline Gonocaryum gracile & Icacinaceae & - & - & - & 0.27 & - \\
\hline Gonystylus maingayi & Thymelaeaceae & - & 4.24 & 0.24 & 2.89 & - \\
\hline Gordonia penangensis & Theaceae & - & 0.69 & 0.98 & - & 1.77 \\
\hline Guioa sp. & Sapindaceae & - & - & - & - & - \\
\hline Homalium longifolium & Flacourtiaceae & - & - & 1.95 & - & - \\
\hline Hopea sulcata & Dipterocarpaceae & - & - & 0.84 & - & - \\
\hline Horsfieldia fulva & Myristicaceae & & - & 1.12 & - & - \\
\hline
\end{tabular}




\begin{tabular}{|c|c|c|c|c|c|c|}
\hline Species & Family & T1 & T2 & T3 & $\mathrm{T} 4$ & T5 \\
\hline Horsfieldia sucosa & Myristicaceae & 0.74 & - & - & - & - \\
\hline Horsfieldia tomentosa & Myristicaceae & 0.19 & - & - & - & - \\
\hline $\begin{array}{l}\text { Hosfieldia polyspherula var. } \\
\text { sumatrana }\end{array}$ & Myristicaceae & - & - & - & - & 0.57 \\
\hline Hunteria zeylanica & Apocynaceae & - & - & 3.41 & - & - \\
\hline Hydnocarpus woodii & Flacourtiaceae & 1.72 & - & - & - & - \\
\hline Intsia palembanica & Leguminosae & 12.80 & - & - & - & - \\
\hline Irvingia malayana & Irvingiaceae & - & - & - & 0.58 & - \\
\hline Ixonanthes icosandra & Ixonanthaceae & - & 3.28 & 0.61 & - & 0.81 \\
\hline Kibatalia maingayi & Apocynaceae & 0.31 & - & - & - & - \\
\hline Knema furfuracea & Myristicaceae & - & - & - & 1.46 & 0.96 \\
\hline Knema hookeriana & Myristicaceae & 1.70 & 0.27 & - & - & - \\
\hline Knema intermedia & Myristicaceae & 1.62 & 0.60 & - & - & - \\
\hline Knema laurina & Myristicaceae & 0.38 & - & - & - & - \\
\hline Knema patentinervia & Myristicaceae & - & 1.53 & 1.35 & 2.51 & 0.30 \\
\hline Knema scortechinii & Myristicaceae & 1.78 & 0.43 & - & - & - \\
\hline Knema stenophylla & Myristicaceae & - & - & - & - & 0.57 \\
\hline Koompassia excelsa & Leguminosae & - & 2.08 & - & 2.79 & - \\
\hline Koompassia malaccensis & Leguminosae & 0.97 & 14.87 & 7.90 & - & - \\
\hline Lasianthus sp. & Rubiaceae & - & - & - & 0.34 & - \\
\hline Lithocarpus curtisii & Fagaceae & - & - & - & 3.48 & - \\
\hline Litsea machilifolia & Lauraceae & - & - & - & 0.26 & - \\
\hline Macaranga hypoleuca & Euphorbiaceae & - & - & - & 0.94 & 0.33 \\
\hline Macaranga lowii & Euphorbiaceae & - & - & 1.06 & 0.78 & 2.57 \\
\hline Magnolia liliifera & Magnoliaceae & - & - & 1.07 & - & - \\
\hline Mallotus leucodermis & Euphorbiaceae & 6.22 & 1.05 & - & - & - \\
\hline Mallotus oblongifolius & Euphorbiaceae & 0.24 & - & 0.24 & - & - \\
\hline Mallotus sp. & Euphorbiaceae & 1.70 & - & - & - & - \\
\hline Mangifera griffithii & Anacardiaceae & - & - & - & 1.33 & - \\
\hline Medusanthera gracilis & Icacinaceae & - & - & 0.21 & - & 0.45 \\
\hline Meiogyne monosperma & Annonaceae & - & 0.27 & - & - & - \\
\hline Memecylon minutiflorum & Melastomaceae & - & 0.26 & - & - & - \\
\hline Memecylon pubescens & Melastomaceae & - & 0.87 & - & - & - \\
\hline Mesua ferrea & Guttiferae & - & - & 0.21 & - & - \\
\hline Mesua lepidota & Guttiferae & 1.00 & - & - & - & - \\
\hline
\end{tabular}




\begin{tabular}{|c|c|c|c|c|c|c|}
\hline Species & Family & T1 & T2 & T3 & $\mathrm{T} 4$ & T5 \\
\hline Mesua racemosa & Guttiferae & - & - & - & - & 0.47 \\
\hline Mezzettia elliptica & Annonaceae & - & - & - & - & 2.54 \\
\hline Microcos antidesmifolia & Tiliaceae & - & 0.72 & - & - & - \\
\hline Microcos fibrocarpa & Tiliaceae & 0.17 & - & - & - & - \\
\hline Microcos laurifolia & Tiliaceae & - & 1.26 & - & - & - \\
\hline Microcos tomentosa & Tiliaceae & - & 0.16 & - & - & - \\
\hline Monocarpia marginalis & Annonaceae & - & - & 0.35 & - & - \\
\hline Myristica gigantea & Myristicaceae & - & - & - & - & 1.81 \\
\hline Nauclea officinalis & Rubiaceae & - & - & - & 1.89 & - \\
\hline Neoscortechinia kingii & Euphorbiaceae & - & - & 0.23 & - & - \\
\hline $\begin{array}{l}\text { Nephelium costatum sub-species } \\
\text { oppoides }\end{array}$ & Sapindaceae & - & 0.41 & - & - & - \\
\hline Nephelium cuspidatum & Sapindaceae & 4.77 & - & - & 1.05 & - \\
\hline Nephelium maingayi & Sapindaceae & - & 0.16 & - & 1.62 & - \\
\hline Nothaphoebe umbelliflora & Lauraceae & 0.90 & - & - & - & - \\
\hline Ochanostachys amentacea & Olacaceae & 1.10 & - & 0.12 & - & 0.47 \\
\hline Palaquium clarkeanum & Sapotaceae & - & - & - & 0.75 & - \\
\hline Palaquium gutta & Sapotaceae & - & - & 2.01 & 4.02 & 1.22 \\
\hline Palaquium hexandrum & Sapotaceae & - & - & 0.64 & - & - \\
\hline Palaquium hispidum & Sapotaceae & - & 2.71 & - & - & - \\
\hline Palaquium maingayi & Sapotaceae & - & - & 2.83 & - & - \\
\hline Palaquium microcarpum & Sapotaceae & - & 0.57 & - & - & - \\
\hline Parartocarpus venenosus & Moraceae & - & - & 0.39 & - & - \\
\hline Paratocarpus bracteatus & Moraceae & - & - & - & 1.72 & - \\
\hline Paropsia vareciformis & Passifloraceae & - & 0.23 & - & - & - \\
\hline Payena dasyphylla & Sapotaceae & - & - & 0.94 & - & - \\
\hline Payena lanceolata var. lanceolata & Sapotaceae & - & - & - & 5.07 & - \\
\hline Payena maingayi & Sapotaceae & - & 1.88 & - & - & - \\
\hline Pellacaly $x$ saccardianus & Rhizophoraceae & - & - & - & 0.67 & - \\
\hline Pentace curtisii & Tiliaceae & 0.17 & - & - & - & - \\
\hline Pentace strychnoidea & Tiliaceae & - & - & - & - & 0.98 \\
\hline Pentaspadon velutinus & Anacardiaceae & 7.40 & 7.76 & - & - & - \\
\hline Pimelodendron griffithianum & Euphorbiaceae & 0.62 & - & 3.51 & 0.72 & 0.14 \\
\hline Planchonia grandis & Lecythidaceae & - & - & - & 2.71 & - \\
\hline Polyalthia jenkensii & Annonaceae & - & 0.56 & - & - & 0.13 \\
\hline
\end{tabular}




\begin{tabular}{|c|c|c|c|c|c|c|}
\hline Species & Family & T1 & T2 & T3 & $\mathrm{T} 4$ & T5 \\
\hline Polyalthia rumphii & Annonaceae & - & 1.08 & - & - & - \\
\hline Pometia ridleyi & Sapindaceae & 2.65 & - & - & - & - \\
\hline Pseudoclausena chrysogyne & Meliaceae & - & 0.29 & - & - & - \\
\hline Pternandra echinata & Melastomaceae & - & - & - & 0.38 & - \\
\hline Pterocymbium javanicum & Sterculiaceae & 1.44 & - & - & - & - \\
\hline Ptychopyxis caput-medusae & Euphorbiaceae & 3.29 & - & - & - & - \\
\hline Pyrenaria acuminata & Theaceae & - & - & - & 0.75 & - \\
\hline Santiria griffithii & Burseraceae & - & - & 0.18 & - & - \\
\hline Santiria laevigata & Burseraceae & 1.03 & 0.96 & 10.47 & - & - \\
\hline Santiria sp. & Burseraceae & 0.17 & - & - & - & - \\
\hline Santiria tomentosa & Burseraceae & - & - & - & - & 1.64 \\
\hline Sapium baccatum & Euphorbiaceae & - & 6.52 & - & - & - \\
\hline Saraca declinata & Leguminosae & - & 0.46 & 0.25 & - & - \\
\hline Sarcotheca griffithii & Oxalidaceae & - & - & - & - & 0.24 \\
\hline Scaphium linearicarpum & Sterculiaceae & 1.13 & - & - & - & - \\
\hline Scaphium macropodum & Sterculiaceae & - & - & - & - & 0.26 \\
\hline Schoutenia accrescens & Tiliaceae & - & 0.20 & - & - & - \\
\hline Shorea leprosula & Dipterocarpaceae & 5.18 & - & - & 12.67 & 6.73 \\
\hline Shorea multiflora & Dipterocarpaceae & - & - & - & 3.26 & - \\
\hline Shorea ovalis & Dipterocarpaceae & - & - & 0.28 & - & 6.19 \\
\hline Shorea parvifolia & Dipterocarpaceae & 3.15 & - & 2.86 & - & 0.28 \\
\hline Species $A$ & Meliaceae & 0.73 & - & - & - & - \\
\hline Streblus elongatus & Moraceae & 0.88 & - & - & - & - \\
\hline Strombosia ceylanica & Olacaceae & - & - & - & - & 0.62 \\
\hline Strombosia javanica & Olacaceae & - & 1.33 & - & - & - \\
\hline Strombosia sp. & Olacaceae & - & - & - & 8.59 & - \\
\hline Styrax benzoin & Styraceceae & - & 0.50 & - & - & - \\
\hline Symplocos fasciculata & Symplocaceae & 2.37 & 1.75 & - & - & - \\
\hline Symplocos sp. & Symplocaceae & - & - & - & 1.00 & - \\
\hline Syzygium chloranthus & Myrtaceae & 0.63 & - & - & - & - \\
\hline Syzygium densiflora & Myrtaceae & - & - & - & 0.25 & - \\
\hline Syzygium duthieanum & Myrtaceae & 0.32 & - & - & - & - \\
\hline Syzygium griffithii & Myrtaceae & - & - & 0.13 & 3.46 & 0.33 \\
\hline Syzygium lineatum & Myrtaceae & 0.90 & - & - & - & - \\
\hline Syzygium protulata & Myrtaceae & 0.69 & - & - & - & - \\
\hline
\end{tabular}




\begin{tabular}{llccccc}
\hline Species & Family & T1 & T2 & T3 & T4 & T5 \\
\hline Syzygium pustulatum & Myrtaceae & - & - & 0.24 & - & - \\
Syzygium sp. & Myrtaceae & 0.79 & 1.38 & 9.23 & 0.92 & 1.32 \\
Tarenna mollis & Rubiaceae & 1.13 & - & - & - & - \\
Teijsmanniodendron coriaceum & Verbenaceae & - & - & 1.11 & - & 2.35 \\
Terminalia citrina & Combretaceae & - & 7.03 & - & - & - \\
Timonius wallichianus & Rubiaceae & 1.35 & - & - & - & - \\
Vernonia arborea & Compositae & - & 0.59 & - & - & 0.64 \\
Vitex pinnata & Verbenaceae & 1.35 & - & - & - & - \\
Xanthophyllum griffithii & Polygalaceae & - & - & 0.35 & - & 1.53 \\
Xanthophyllum lelacarum & Polygalaceae & - & - & 10.08 & - & - \\
Xerospermum laevigatum & Sapindaceae & - & 0.50 & - & - & - \\
Xerospermum noronhianum & Sapindaceae & - & 3.94 & - & - & - \\
Xylopia magna & Annonaceae & - & 7.76 & - & - & - \\
Xylopia malayana & Annonaceae & - & 0.16 & - & - & 0.43 \\
\hline
\end{tabular}

Table 5. List of species, family and the relative basal area of Kuala Keniam forest.

\section{Author details}

Mohd Nazip Suratman

Faculty of Applied Sciences, University of Technology MARA, Shah Alam, Malaysia

\section{References}

Ashton, P. S. 1964. A quantitative phytosociological technique applied to tropical mixed rainforest vegetation. Malays. For., 27, 304-307.

Bernhard-reversat, F, Huttel, C., and G. Lemee. 1978. Structure and functioning of evergreen rain forest ecosystem of the Ivory Coast. In: Tropical Forest Ecosystems: A State-ofKnowledge Report, UNESCO, Paris, pp. 557 - 574.

Bray, J. R. and J. T. Curtis. 1957. An ordination of upland forest communities of southern Wisconsin. Ecological Monographs 27:325-349.

Burgess, P. F. 1961. The structure and composition of lowland tropical rain forest in north Borneo. Malays. For., 24: 66-80.

Changcheng, T., Xuelong, J., Hua, P., Pengfei, F. and Z. Shoubiao. 2007. Tree species diversity of black-crested gibbons (Nomascus concolor). Acta Ecologica Sinica. 27(10): $4002-4010$.

Campbell, D.G., J.L. Stone and A. Rosas Jr. 1992. A comparison of the phytosociology and dynamics of three floodplain (Varzea) forest of known ages, Rio Jurua, western Brazilian Amazon. Botanical Journal of the Linnean Society 108: 231-237. 
Cannon, C.H., Peart, D.R., and M. Leighton. 1998. Tree species diversity in commercially logged Bornean rain forest. Science 28, 1366-1368.

Condit, R., Hubbell, S.P., La Frankie, J.V., Sukumar, R., Manokaran, N., Foster, R.B. and P.S. Ashton. 1996. Species-area and species-individual relationships for tropical trees a comparison of three 50 ha plots. J. Ecol. 84, 549-562.

Dagar, R. J. C. and N.T. Singh. 1999. Plant Resources of the Andaman and Nicobar Islands, Vol. 81, 211-0165.

Ferreira, L. V. and G.T. Prance. 1998. Species richness and floristic composition in four hectares in the Jaú National Park in upland forests in Central Amazonia. Biodivers. Conserv , 7, $1349-1364$.

Gentry, A.H. 1988. Changes in plant community diversity and floristic composition on environmental and geographic gradients. Annals of the Missouri Botanical Garden. 75 $1-34$

Gentry, A.H. 1990. Floristic similarities and differences between southern Central America and upper and central Amazonia. In: Gentry, A.H. (Ed,) Four Neotropical Rainforests. Yale University Press, New Haven, CT, pp. 141 - 157.

Gentry, A.H., 1992. Tropical forest biodiversity: distributional patterns and their conservational significance. Oikos 63, 19-28.

Hubbell, S.P., Foster, R.B., O’Brien, S.T., Harms, K.E., Condit, R., Wechsler, B., Wright, S.J. and S. Loode Lao. 1999. Light-gap disturbance, recruitment limitation, and tree diversity in a Neotropical forest. Science 283, 554-557.

Kent, M., and P. Coker. 1992. Vegetation description and analysis: a practical approach. Belhaven Press, London.

Knight, D. H. 1975. A phytosociological analysis of species rich tropical forest on Barro Colorada Islands, Panama. Ecol. Monogra., 45, 259-284.

Magurran, A.E. 1988. Ecological Diversity and Its Measurement. Princeton University Press, Princeton, $\mathrm{N} \mathrm{J}$.

Margalef, F. R. 1958. Information theory in ecology. Gen. Syst., 3:36-71.

Okuda, T., Suzuki, M., Adachi, N., Quah, E. S., Hussein, N. A. And N. Manokaran. 2003. Effect of selective logging on canopy and stand structure and tree species composition in a lowland dipterocarp forest in Peninsular Malaysia. Forest Ecology and Management 175: 297-320.

Philips, O.L. and A.H. Gentry. 1994. Increasing turnover through time in tropical forests. Science. 263, $954-958$.

Preston, F.W. 1962. The canonical distribution of commonness and rarity, Part I. Ecology, 43:185 - 215.

Richards, P. W. 1952. The Tropical Rain Forest, Cambridge University Press.

Richards, P. W. 1996. The Tropical Rain Forest: An Ecological Study, Cambridge University Press, Cambridge.

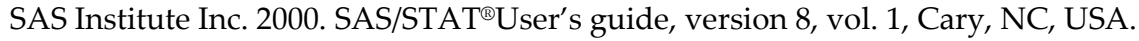

Shannon, C. E. and W. Weiner, 1949. The Mathematical Theory of Communication, University of Illinois Press, Urbana, USA.

Simpson, E. H. 1949. Measurement of diversity. Nature, 163: 688. 
Singh, J. S., Singh, S. P., Saxena, A. K. and Y.S. Rawat. 1981. Report on the Silent Valley Study, Ecology Research Circle, Kumaun University, Nainital, 86.

Singh, J.S., 2002. The biodiversity crisis: a multifaceted review. Curr. Sci. 82, 638-647.

Sumina, O.I., 1994. Plant communities on anthropogenically disturbed sites on Chukotka Peninsula, Russia. J. Veg. Sci. 5, 885-896.

Suratman, M.N., M. Kusin, and S.A.K. Yamani. 2007. Study of tree species composition in Sungkai Forest. Paper presented at the National Biodiversity Seminar, Department of Wildlife and National Parks. 20 - 21 Nov. 2007, Seremban.

Suratman, M.N., M.S. Daim, S.A.K. Yamani, M. Kusin and R. Embong. 2009. Report of Flora and Fauna Surveys for Sungai Sator Forest, Jeli, Kelantan. Environmental Impact Assessment (EIA) Report for the Development of UMK campus. 26pp.

UNEP, 2001. India: State of the Environment. United Nations Environment Programme.

Waide, R.B., Willig, M.R., Steiner, C.F., Mittelbach, G., Gough, L., Dodson, S.I., Juday, G.P. and R. Parmenter. 1999. The relationship between productivity and species richness. Annu. Rev. Ecol. Systematics, 30, 257 - 300.

Wang, D.P., Ji, S.Y., Chen, F.P., Xing, F.W. and S. L. Peng. 2006. Diversity and relationship with succession of naturally regenerated southern subtropical forests in Shenzhen, China and its comparison with the zonal climax of Hong Kong. Forest Ecology and Management 222: 384-390.

Whitmore, T. C. 1998. An Introduction to Tropical Forests, Clarendon Press, Oxford and University of Illinois Press, Urbana, $2^{\text {nd }}$, Ed. pp. 117.

Whitmore, T.C. 1984. Tropical Rain Forests of the Far East. Clarendon Press, Oxford.

Whittaker, R. H. 1972. Evolution and measurements of species diversity. Taxon, 21: 213-251. 